\title{
The Utilization of Historical Laboratory as A History Learning Media in University PGRI Yogyakarta
}

\author{
Nadhira Nikmatullah \\ Universitas Negeri Yogyakarta \\ Yogyakarta, Indonesia \\ nadhira0090pasca2016@student.uny.ac.id
}

Abstract-This research is a qualitative research with descriptive approach. Resource persons in this research were laboratory head, laboratory manager, lecturers and students. Data collection in this research used interview method, observation and documentation. Data validity used two triangulation techniques, source triangulation and engineering triangulation. Data analysis techniques used Miles and Huberman model that is data collection, data reduction, data display, and conclusion drawing/ verification (conclusion/ verification). The results concluded that students and lecturers had utilized the Laboratory and Media Laboratory collection media as a media in the history of the learning process even though in its application there were still shortcomings. Students used collection media as a visual media to explain the material delivered during the learning process. Researcher used was a record of the attendance list of lectures and notes on the results of progress in the lecture process. Laboratory utilization practices were also applied to theoretical and laboratory applications, where students were taught the theory and utilization of laboratories. In accordance with the notes on the results of progress in the lecture process, history education students got very satisfying grades related to the subject and the learning process in the History laboratory.

Keywords-media, learning, history, laboratory.

\section{INTRODUCTION}

Yogyakarta PGRI University is located on Jl. PGRI 1 Sonosewu No. 117, Ngestiharjo, Kasihan, Bantul Regency, Special Region of Yogyakarta 55182. Below will be explained the vision and mission, objectives, functions, curriculum books, facilities and infrastructure as well as management and History Laboratory Staff at Yogyakarta PGRI University [6].

The History Education Department of the University of PGRI Yogyakarta has a Laboratory which is divided into 3 spaces, namely: The AudioVisual room (AVA Room), Display room, Workshop room. Audio Visual Space is a space that functions as a place for performances and other activities that are classical in nature. So that it is equipped with seating and audio and visual electronic media that already uses digital. This space is designed for lecture activities, seminars, historical film screenings. Following are the Laboratory room plans and media collections owned

\author{
Wasino \\ Semarang State University \\ Semarang, Indonesia \\ wasino@mail.unnes.ac.id
}

by the Department of Historical Education at the PGRI University of Yogyakarta, which are as follows:

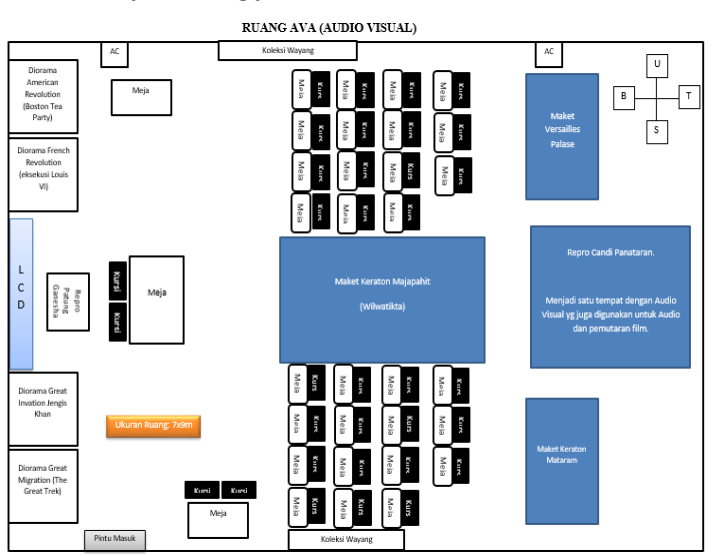

Fig. 1. Audio Visual Room
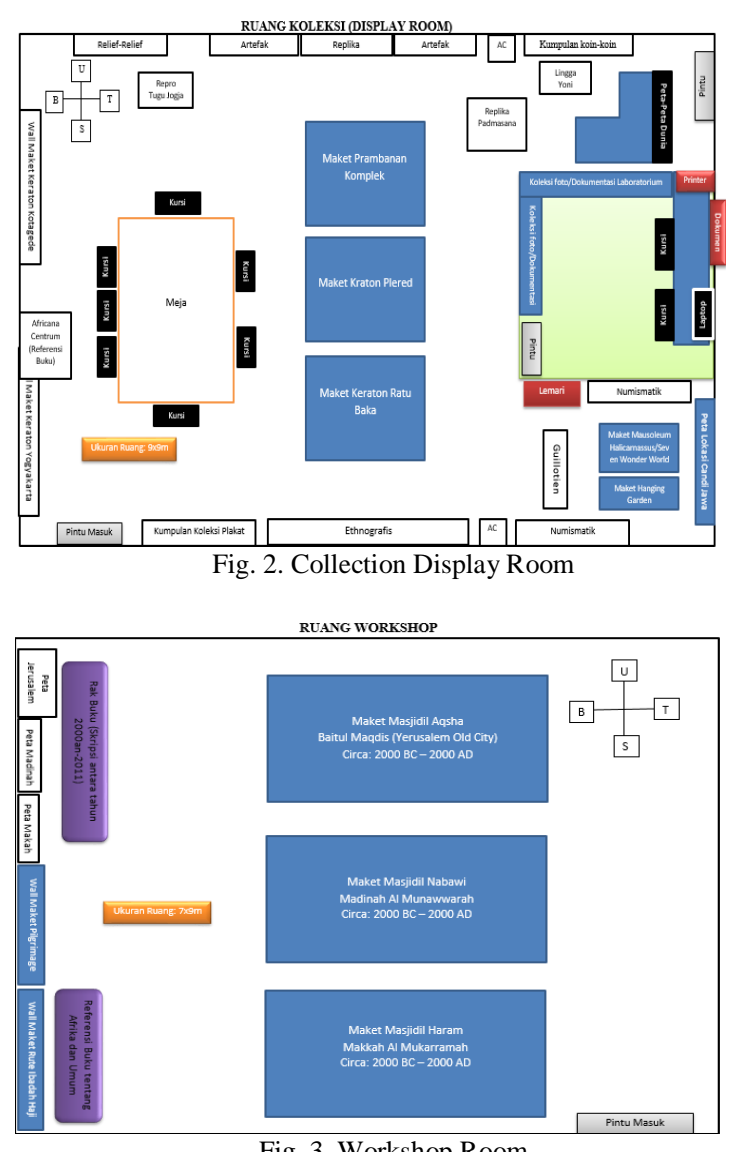

Fig. 3. Workshop Room 
The implementation of education is a process of civilizing and empowering students that lasts for life. In the process, the role of educators who are able and willing to be role models is needed to build abilities and develop the potential and creativity of students. This principle causes a paradigm shift in the educational process from the teaching paradigm to the learning paradigm [5]. This implies that students occupy the main positions that get full attention and service to enjoy educational facilities so that they can develop their talents and creative abilities optimally. In this case educators also have a role as the spearhead to direct students to develop their abilities.

The article is the basis for developing the character and skills of students, especially the younger generation. The development of human capacity as a young generation can be pursued through various efforts, including through education that is carried out in a programmed, gradual, and continuous manner [1]. One of them is by providing history education material to students during the learning process is very important to do, it aims to make students become wise individuals who can see an event, also make students more competent, and independent are also responsible in addressing every event. In the history education material that is distinctive and rich in historical values is the strongest potential to introduce students to the nation and its aspirations in the past. This value is very important to be taught so that students are wiser in responding to every event that occurs.

Indirectly through history learning, students can study what and if, why, how, and the consequences of what came from the answers of the past society to the challenges they face and their impact on life in the aftermath of the event and the present. Historical material can develop the potential of students to recognize the values of the nation that were championed in the past, maintained and adapted for the present life, and further developed for future life. The nation of Indonesia today and all the values and lives that occur are the result of the nation's struggle in the past which later became capital for the struggle of life in the future [2]. History lessons teach students how each past event has an impact on the present. Through historical lesson material, students are taught to be more careful in every action that will be taken.

Historical material provides information about the successes and failures of the nation in answering the challenges of the times so that they belong to the nation of today. What actions are carried out by historical actors who failed in achieving the goals and actions they did that achieved their goals. The material listed in the historical story is not only a success story but also a story of failure. Successes and failures are things that happen in real life. Both sides of life can be an important lesson. Historical education material in developing character education, material for developing historical education function as an example bank to solve current problems and prepare themselves for future events [8]. Historical material teaches students to be wiser, appreciate and benefit from past events. The selection of good media in the learning process can speed up delivery and increase the effectiveness of the characteristics of historical subjects. Historical subjects are not merely considered boring as most people think. But it becomes a fun lesson because it becomes a mirror for every future action.

According to learning media is a measuring tool that functions and is used to convey learning objectives [4]. In the process of learning activities, the presence of the media has an important meaning because the constraints of unclear material presented by educators can be helped by presenting the media as an intermediary. Material difficulties presented by educators to students can be overcome with the help of media. Therefore, learning media can be used as a channel for messages to achieve learning goals.

Most teachers / lecturers use the media not based on the choice of media on logical and scientific thinking, but rather because they follow the development of technological advances or because they follow the habits that develop in the school environment. Not a few also, in the teaching and learning process in the classroom the instructors familiarize the use of media that has been provided by the school, so that the use of the media is not based on conformity with the objectives, material and characteristics of students [3]. From this statement it can be concluded that most lecturers / teachers use the media only as an alternative facility which, if used, makes the learning process a little different from the non-use of the media as a tool. The use of media is often not appropriate or not in a state of great need but only formality so that the media is not in vain and used.

The history laboratory at Yogyakarta PGRI University has been used well, history lecturers have utilized the History laboratory as a historical learning media. Every teaching material or subject that has a connection with the collection, the lecturer always invites students to the history laboratory. This is done so that students in addition to understanding also know the form of collections related to teaching materials. The study program also supports the use of historical laboratories by requiring all history lecturers to utilize laboratory collections as learning media. The history laboratory at Yogyakarta PGRI University has a variety of collections that make history laboratories at Yogyakarta PGRI University one of the most comprehensive historical laboratories.

\section{METHOD}

The method used in this research is descriptive qualitative research method. This research will explain what it is about how to use the history laboratory as a media for learning history at Yogyakarta PGRI 
University. The presence of researchers does not affect the use of historical laboratories as a media for learning history at Yogyakarta PGRI University. The researcher did not give treatment to the subjects studied. The results of this study are not in the form of numerical data but in-depth descriptions of the use of historical laboratories as a media for learning history at Yogyakarta PGRI University.

The research technique used in this study is:

\section{A. Observation}

Observation is data collection done by observing and systematically recording the object under study, both in special situations in the laboratory and in natural situations. Data collection techniques through observation techniques are usually used to measure individual behavior or the process of occurrence of an observable event, such as the ongoing process of classroom learning. Because the observation process is done by seeing and listening, non-physical activities are very difficult to observe [8].

\section{B. Interview}

The type of interview used in this study is semistructured interviews. According to Esterberg semistructured interviews aim to find problems more openly, where the interviewees are asked for their opinions and ideas [7]. The researcher listened carefully and recorded what was said by the informant.

\section{Documentation}

According to Sugiyono Documentation is a record of past events [7]. The documentation method is to collect data from reports that are written, illustrated or printed that are used by researchers to help the research carried out.

The strategy used in this study is a case study. Because the problems and research focus have been determined in the proposal before going into the field, then this type of research strategy can be more specifically referred to as a fixed case study. According to Sutopo in in the research, the researcher has chosen and determined the variables which are the focus before entering the field of study [4]. In this study the target studied has been determined before the researcher goes into the field. The speakers used in this study were the Head of the laboratory, the laboratory manager, lecturers and students. The object of research is only one, namely, the use of historical laboratories as a learning media for history.

\section{RESULT AND DISCUSSION}

The laboratory is used as a media in the learning process. The laboratory is also used as a room to plan a collection concept to be worked on. In the laboratory there are various tools and equipment that are used as a tool as well as a historical learning space. The laboratory acts as a tool to encourage the effectiveness and optimization of the learning process through the implementation of various functions which include service functions, procurement functions, development functions and research functions, learning media and other functions relevant to improving the efficient effectiveness of learning.

As a service function: in addition to being used by students as lecture halls and practices, the History Laboratory at Yogyakarta PGRI University which has three main rooms of separate laboratories is open to the public and is often visited by various agencies and the general public. History laboratories also often get visits from several universities for comparative studies, high school and junior high school students. The History Laboratory has also been visited by important figures from domestic and abroad who want to see what collections they have and how they are used.

As a procurement function: historical laboratories have been used by lecturers as an alternative media in the learning process. The use of various media in the learning process helps lecturers avoid monotonous learning processes, because using the same method will cause boredom and boredom in the acceptance of material. In addition to creating an active atmosphere and changing atmosphere during learning, the use of laboratories also helps lecturers in delivering material better.

Development function: development can be seen in the digitization process. Digitization efforts are carried out to facilitate the use of laboratory collections in the learning process. During the process of digitizing the laboratory collection, such as maket collections were made audio by adding sound applications to each collection, this was done to save time that is commonly used to explain material from collections that had been described manually by Historical Laboratory officers. During the process of digitizing the institution was constrained by the limited funds that made the digitization process not immediately realized.

Research function and learning media: History Laboratory Yogyakarta PGRI University has various complete collections because it consists of various types, sizes, and shapes, many benefits that can be obtained by visitors and students while using collections. The laboratory is used as a place for making collection media. Almost all laboratory collections are the result of collaboration between lecturers and students. Besides being used as a place to make collections and laboratory lecture halls, it is also used as a place to store reference books. Reference books are also used by lecturers for the provision of historical material.

In the laboratory there are various kinds of historical collections that can be used as a media to facilitate the process of learning history, as well as a means of education for laboratory visitors. In order to maximize the utilization of the Laboratory, the Department of History Education is trying to develop 
by including the History Laboratory to become one of the members of Barahmus. This effort is carried out for the purpose and utilization of the laboratory in history learning becomes more maximal.

The benefits obtained in the use of collection media during the learning process in addition to increasing knowledge, students have a picture of how historical processes occur. The use of media makes students understand how the mini form of a historical heritage, the process of making, information, and history contained in the collection. In addition to increasing students' insight into the use of the History Laboratory, students are also equipped with skills on how to make a Laboratory collection which in the future will be a provision for students when going into the world of work.

During the process of making student collections, they also took part in making laboratory collections. Collection is also adjusted to the historical learning material used and that is in the curriculum. During the lecture process students use the Laboratory collection as a tool to present how to use a History Laboratory collection. In lectures, students also get group assignments specifically discussing laboratories and their collections.

The use of media during the learning process makes students understand how the planning process and the concept of making a collection, data/ material collection, as well as the process of making it because during the process students are also involved in the process of making laboratory collections. Student involvement during the collection process will improve student skills on how to make a historical collection.

During the process of making the lecturer collection is an important element in both the individual program and as a mentor. Each Laboratory lecturer is required to make a work plan per semester / year in accordance with the general laboratory program such as making modules, guiding student field studies, guiding student field studies, guiding laboratory student work, lecturers are also required to coordinate students which is the responsibility of students to carry out tasks according to the program which has been specified

The use of collections in the learning process also makes students more enthusiastic in understanding learning material. The existence of collection media used in the learning process makes students more creative in utilizing and developing development ideas about the History Laboratory. The use of media in the learning process makes students understand how to use a media in learning. Because the existence of a real form of a laboratory collection makes students easier to remember a historical event. The memory of how to remember students correctly is the form of a historical heritage that can be obtained using a laboratory collection.

\section{CONCLUSION}

The existence of the Laboratory for the Department of History Education itself is very helpful in the lecture process as well as a place to exhibit collections. For Yogyakarta PGRI University, the existence of this laboratory itself is a matter of pride, because the laboratory is considered as an icon for the department or the University, how cannot be separated from the purpose of each guest visiting the Yogyakarta PGRI University will be invited to visit the laboratory.

In addition to being used to showcase collections, the History Laboratory is also used to store collection media which in practice is used as a media collection laboratory to support the learning process. Every learning material that requires the media in the learning process will use laboratory collection media. Many collections that are commonly used by students consist of models, dioramas, and sculptures that are adapted to the material. In addition to using media collection students also use literature books as a reference for doing lecture assignments. The PGRI University history laboratory has a collection of history books that are practically complete. Reference collections consist of reference books making laboratory collections, general collections, as well as alumni theses majoring in History Education.

The use of the History Laboratory helps students understand what benefits are obtained by using laboratories, especially media collections in the laboratory. The use of the History Laboratory makes students understand that in the laboratory there are many collection media that can be used. In practice students can use collection media and historical reference books to support the learning process. In addition to being used as a medium for learning, historical laboratories can also become mini libraries that contain historical reference books and theses which become one of the History Laboratory collections

\section{REFERENCES}

[1] Hasan. Development of National Cultural and Character Education, Jakarta: Puskur Research and Development, 2010.

[2] Hasan, S. H. Historical Education to Strengthen Character Education. Paramita. Vol. 22 No. January 1, 2012. Retrieved from http://bit.ly/2hETHkj.

[3] Munadi, Y. Learning Media - A New Approach. Jakarta: GP Press Group, 2013.

[4] Nuryanti. Use of Media Laboratories in History Learning (Case Study of Semarang Veterans Ikip History Laboratory). Satya Widya Journal, Vol. 32, No.1. June 2016. Retrieved from

http://ejournal.uksw.edu/satyawidya/article/download/627/42 0 .

[5] Pristine A, D and Suryani, E. Implementation of Character Building in State Junior High School 1 Jember Embankment. Character Education Journal, Year V, Number 1, April 2015. Retrieved from http://bit.ly/2yHDZQd. 
[6] Siswanta, Darsono \& Sudartoyo. History Laboratory (History Education Study Program, Teaching and Education Faculty Yogyakarta PGRI University, 2017

[7] Sugiyono. Educational Research Methods: Quantitative, Qualitative and R \& D Approaches. Bandung: Alfabeta, 2013.

[8] Triyono. Educational Research Methodology. Yogyakarta: Waves, 2013.

[9] Wineburg, S. Historical Thinking: Mapping the Future, Teaching the Past. Bro. Masri Maris. Jakarta: Yayasan Obor Indonesia, 2006. 